\title{
Nurse's perception of patient safety culture in an effort to improve service quality in the operating room of Riau Province Hospital
}

\author{
Yulisnawati $^{1}$, Zulfendri $^{2}$, Siti Saidah Nasution ${ }^{2}$ \\ ${ }^{1}$ Master Student in Universitas Sumatera Utara (USU), Medan, Indonesia \\ ${ }^{2}$ Lecturer in Universitas Sumatera Utara (USU), Medan, Indonesia \\ Email: yulis_nawati@yahoo.com
}

\begin{abstract}
:
The aim of the study is to find out Nurse's perception of patient safety culture in an effort to improve service quality. This study uses qualitative research methods with a phenomenological approach. The result of the study is obtained that the informants assume that the socialization carried out by the hospital in the context of increasing knowledge related to patient safety is not effective. Education and training for patient safety is carried out continuously to increase knowledge, improve and maintain staff competence. While the socialization carried out by the hospital did not have much influence to increase the informant's knowledge related to patient safety.

Keywords:

Nurse's perception; patient safety; service quality
\end{abstract}

\section{Introduction}

Nurses are the most paramedics available at the hospital and are on duty 24 hours serving patients. Nurses play an important role in improving patient safety, namely as a provider of information to patients and families about the likelihood of an incident occurring, reporting if an incident occurs, improving communication with patients, patients' families and other medical personnel, as well as playing an active role in assessing safety and quality service and help measure the improvement of patient safety (Choo, 2010).

Research on nurses' perceptions about patient safety culture has been carried out, according to research conducted by the AHRQ (Agency for Healthcare Research and Quality) in 2018 which stated that only 63 percent of nurses had positive perceptions of patient safety culture. Another study conducted by Alquwez (2017) at Saudi Arabia and Ammouri hospitals (2015) in Oman found that nurses' positive perception of patient safety culture was still very low.

The medical risk due to surgery in developing countries is 19 percent higher when compared to developed countries, and 25 percent of the drugs used in developing countries are fake. Of the 20 countries surveyed by WHO, 60 percent of patient safety incidents and the use of fake drugs occur in developing countries. Other research shows that medical equipment in developing countries is almost half unsuitable for use and rarely receives periodic maintenance. Indonesia is one of developing countries and potential for patient safety incidents (Purwanto, 2018).

Data on patient safety incidents in Indonesia is very minimal due to the lack of culture to report when patient safety incidents occur. But we still see a lot in the media that there are many mall practices in hospitals, this indicates that there are still many patient safety incidents that occurred in Indonesia. According to the National Hospital Patient Safety Commission (KNKPRS) in 2019 the number of injuries was almost 2534, the number of non-injuries was 
2554, and the number of unexpected events was 2567 cases. While 243 deaths were caused, 89 severe injuries, 449 moderate injuries, 1247 minor injuries and 5630 non-injuries. Many incidents occurred in the productive age group, namely 15-30 years, 1125, and 30-60 years age group, 3821 cases (Ministry of Health) RI, 2019). From the above data, we can see that the number of patient safety incidents in Indonesia is still high and most often in the productive age and of course this is very influential.

The occurrence of patient safety incidents in Riau Province Hospital is one indicator that hospitals have not yet provided quality services. Other indicators of service quality are the number of appropriate sleep usage or Bed Occupancy Rate (BOR) of 45 percent, Average Length of Stay (AVLOS) or the average length of patient treated by 45 days, Bed Turn Over (BTO) is also called the bed turnover rate of 37 times, the Turn Over Interval (TOI) of six days.

\section{Review of Literature}

\subsection{Perception}

According to Sthepens P. Robbins (2008) perception is the process by which individuals or individuals organize and interpret the sensory impressions they feel in order to give meaning to their environment. Another definition of perception according to Thoha as written by Tahir (2014) is the cognitive process experienced by everyone in understanding information about their environment through vision, appreciation, feeling and smell. According to Rahmat in Tahir (2014) perception is the experience of objects, events or relationships that are obtained by concluding information and interpreting messages.

\section{Factors that influence perception}

There are three factors that influence one's perception according to Sthepens P. Robins (2008) viz:

1. Characteristics of perception maker

When someone sees something and tries to interpret what he sees, then this is influenced by several personal characteristics of the maker of perception, namely attitudes, personality, motives, interests, past experiences and expectations about the maker of perception.

2. Object or target interpreted

The characteristics of the target or object to be interpreted by individuals affect what will be interpreted. The object or target factor that influences one's perception is something new, movement, sound, size, background, closeness, and similarity.

3. Situation

There are 3 situation factors that influence one's perception, namely time, work conditions and social conditions.

Meanwhile, according to Thoha in Tahir (2014) there are three factors that influence perception, namely psychology, family or family such as parents, children and culture. Culture here is the environment and culture in which a person lives.

\subsection{Patient Safety}

Patient safety is protected from preventable dangers and reduces unnecessary minimum risks obtained during the health care process (WHO, 2018). Whereas according to Permenkes NO 11 of 2017 is a system where hospitals make patient care safer. IOM defines that patient safety is preventing harm to patients by providing a good care system, preventing mistakes, learning from mistakes and building a culture of patient safety for all health professionals both nurses, organizations and patients. 
Patient safety or patient safety according to Supari in Purwanto (2018) is free from or avoided a patient from an incident or injury caused by medical care and treatment during the patient being treated. Patient safety is preventing, avoiding and repairing the results of actions that are bad or dangerous for patients who come from the treatment process (Vincent, 2011). Meanwhile, according to Emanuel in Purwanto (2018) said that patient safety is a discipline of nursing and health that emphasizes patient safety to create reliable health services.

Patient safety began to be discussed since the report made by the Institute of Medicine (IOM) in America in 1999 entitled to err is human and an organization with a memory (2000). The results of this study say at least 44,000 to 98,000 people die each year in America due to medical error. In 2008 in the United States 3.2 percent - 5.4 percent, Latin America 10 percent, New Zealand 12.7 percent, Denmark nine percent and Britain 11.7 percent. While in Taiwan there were 14,945 cases reported in 2007.

\subsection{Patient safety culture.}

Patient safety culture must be applied in all parts of the hospital without exception, starting from the system, hospitals, departments and units in all parts. A patient safety culture requires appreciation, support from management. Patient safety culture must also be in accordance with what is desired and must be accepted by all staff in the hospital (AHRQ, 2018).

The core component of patient safety culture. The positive implementation of patient safety culture is influenced by six core components, namely: Leadership culture. According to Huber D in Suarli (2015) leadership is an activity to influence people's behavior so they want to work together to achieve goals or the art of leading to want to influence others to behave as we want. A leader must be able to change the behavior of nurses to work and create a patient safety culture in hospitals, prioritizing that patient safety is the main thing and must be applied in hospitals. The leader not only makes policies but participates in creating a safe culture and rewards nurses who provide services that support patient safety. A leader according to Permenkes no 11 of 2017 on patient safety has duties and roles in order to improve patient safety culture, namely:

\subsection{Quality of Service}

Quality of health services is a health service that is needed, in this case determined by the health care profession, as well as desired by patients at affordable costs. According to The Health Foundation (2013), improving the quality or quality of service is the responsibility and role of all staff in the hospital. Improving quality means making health care / services safer, more effective, patient-centered, timely, efficient and fair.

Quality or quality is the extent to which health services for individuals and the community in order to improve health services desired and carried out professionally (IOM, 2000). Quality includes the ability to do the right things, for the right patient with good results and affordable costs. Quality improvement means that the management process is carried out continuously and organized which involves everyone in the organization in an effort to improve the performance of an organization. Service quality is the effect that results from a complicated but understandable cause and effect service process. The success of an organization to provide quality services depends on how each unit works to meet customer needs, meaning that the quality of service in a hospital depends on how each unit and person in the hospital that is health workers provide services needed by patients (Wright and Hill, 2003). 


\section{Research Method}

This study uses qualitative research methods with a phenomenological approach. Qualitative research is research conducted to obtain answers or in-depth information from an informant about a person's opinions and feelings in the form of behavior, perception, motivation and action (Moleong, 2016).

Phenomenology studies are used as a method of applying qualitative research in order to explore and uncover the common meaning of a phenomenon that is experienced by groups or individuals. This design seeks to understand the meaning of events in certain situations. The advantage of phenomenological design is that it can reveal hidden and real experiences in the psychological and physiological aspects of the informant so that the researcher can understand the experience felt by the informant. The research location is inpatient surgery in Riau Province Hospital. And when this research was conducted from September 2018 until July 2, 2019.

\section{Discussion}

The results obtained that the informants assume that the socialization carried out by the hospital in the context of increasing knowledge related to patient safety is not effective. Education and training for patient safety is carried out continuously to increase knowledge, improve and maintain staff competence. While the socialization carried out by the hospital did not have much influence to increase the informant's knowledge related to patient safety.

Suggestions for increasing knowledge. The results of the interviews obtained related to what advice should be done to improve the knowledge of informants related to patient safety are as follows:

"At least we were given one day of training, this is two days of socialization with lots of information" (P9L124-125)

"The time given for training should be added not only for a short time (P12L73-74)

"I want to hold training at least once a year, so that the knowledge we get is the latest, every year science will continue to develop (P18L37-39)

"... if you want to effectively socialize it over and over" (P29L153-154)

The results of the above study indicate that the informant had hopes that the hospital would conduct special training related to patient safety. Training is not only for accreditation preparation but is carried out on an ongoing basis.

According to research conducted by Fatimah and Rosa (2016) that training is effective in reducing errors in drug administration by injection by nurses. According to Permemkes No 11 of 2017 that every hospital institution has an education and training program that contains topics about patient safety in accordance with their respective duties. Every health facility must integrate patient safety in every training or education activity that is carried out continuously.

The results obtained that nurses' perceptions related to the advice to be done by the hospital is the hospital held special training related to patient safety by increasing training time. Competence is a combination of employees' knowledge, skills and attitudes so that they are able 
to carry out their work well. Competency improvement can be done by providing various types of training for employees. The results obtained in the field that the informants felt the socialization provided was not effective to increase their knowledge because it was delivered in a short time. Apart from a short time, many discussion topics also prevented them from absorbing whatever information was conveyed. The hospital should organize training with adequate time so that the information conveyed can be absorbed by the informant.

Communication about patient safety is still not effective. Effective communication is one of the goals of patient safety that must be implemented. Communication in patient safety is open communication between management, nurses, and patients.

Social acceptability is one of the dimensions of quality of health services according to Maxwell RJ in Wright and Hill (2003) which means hospitals make regulations on how to regulate communication to patients, communication with patients' families and communication in providing care by health workers. When the communication that occurs in the hospital is good, it will be followed by quality service.

There is one theme: the environment does not support communication as shown in the table below:

Table 6. Theme 5 Communication in Supporting Patient Safety Is Not Effective yet

\begin{tabular}{lll}
\hline \multicolumn{1}{c}{ Category } & \multicolumn{1}{c}{ Sub theme } & \multicolumn{1}{c}{ Theme } \\
\hline There is no open & The environment does & 1. Communication in \\
communication & not support & supporting patient \\
Still blaming & communication & $\begin{array}{l}\text { safety has not been } \\
\text { effective }\end{array}$ \\
\hline
\end{tabular}

The environment does not support communication. Communication in patient safety is the absence of open communication and a culture of blame.

There is no open communication. The results of interviews with informants related to whether there is open communication of the policies taken in order to support patient safety are as follows: "How dare we protest, our only protest is here, just us" (P6L233-234)

"Yes, thank you, what do you know about this hospital? Later, when we talk about fear, how will it be immediately stamped? arguably against. It's hard to talk here "(P10L152-154)

"It's lazy to ask, there isn't a solution either, later on we don't think we want to work anymore" (P14L128-129)

"I have, but there is no change because it has become a policy (P16L77)

'It's hard to protest now, we will be deemed not to accept it later (P32L96)

From the interview results above shows that the informant is not free to talk when there is a policy related to patient safety taken by management and afraid if deemed not complying with the policies or regulations made.

According to research conducted by Agustina and Warsito (2018) that effective communication has an important role in patient safety. Meanwhile, according to Sari (2016) who 
conducted research at Medan Hajj Hospital that open communication is important to create patient safety.

Nurse's perception that there is no open communication about patient safety. Informants find it difficult when they have to ask a policy taken by management. The hospital should create open communication between all staff in the hospital, the management and communication to patients that aims to create a culture of patient safety. When open communication has been established, it is hoped that a patient safety culture can be realized.

Still blaming. The results of interviews with related informants whether there is still a response to blame if an incident occurs is as follows:

"How are we going to report to management, let's say, all of you fools ..." (P4L168-169)

"If we report the medicine that forgot the checklist, I don't know what will happen, whatever your work, they will say later. There is no solution that we will also be blamed ...... "(P10L136137)

"They still blame us as nurses, sometimes the wrong ones are not nurses, but they are always blamed, the incident is also discussed ..." (P13L105-107)

"The person must be discussed as well, just when it happened, who was in the service" (P17L96-97)

"If something goes wrong, it remains, what people are discussing, the official is still blamed. The problem is still being discussed, but the person is also .... "(P24L116-118)

"Yes, we are blamed, so we are lazy to report" (P27L71)

"... nurses are also afraid to report" (P31L71)

The interview results show that the informants were still blamed if an incident occurred and they were afraid to report because it was discussed by the relevant officer.

Research conducted by Gunawan (2015) in a hospital in Malang about the cause of the low reporting of patient safety incidents is the fear of nurses to the head of the work unit. At this hospital it was found that the patient safety incident rates were greater than those reported by the patient safety team. Low reporting due to lack of understanding of patient safety incident reporting concepts.

The evaluation is only limited to finding the cause of the patient safety incident. Evaluation of incidents is very important as a lesson so that the same incident does not happen again. Studies in Australia show that 10 percent of all incidents reported nationally will reappear more than once every 2 months, therefore evaluation of incidents is very necessary.

The sub-theme in this study is that there is no learning after a patient safety incident occurs as shown in the table below: 
Table 7. Theme 6 Evaluations are only limited to finding the cause of a patient safety incident

\begin{tabular}{lll}
\hline \multicolumn{1}{c}{ Category } & Sub theme & \multicolumn{1}{c}{ Theme } \\
\hline $\begin{array}{l}\text { Report to supervisor } \\
\text { Look for the root of the } \\
\text { problem }\end{array}$ & $\begin{array}{l}\text { Tidak ada } \\
\text { pembelajaran setelah } \\
\text { terjadi insiden } \\
\text { by the patient safety team }\end{array}$ & $\begin{array}{l}\text { 2. The evaluation is } \\
\text { only limited to } \\
\text { finding the cause of } \\
\text { the patient safety team comes } \\
\text { only when an incident occurs } \\
\text { There is no learning going } \\
\text { forward } \\
\text { No investigation results were } \\
\text { announced }\end{array}$ \\
\end{tabular}

If an incident occurs in a hospital, the first step taken is to investigate the chronology of the incident. The results of the interview regarding the investigation process are as follows:

"Usually in the first trace, ask the nurse" (P3L100)

"After we report to the supervisor, they usually ask us questions, after that the office will come tomorrow to find out what the cause is (P10L156-158)

"They only came to look for the root of the problem, just an investigation" (P16L48-149)

The results of the interview above show that if an incident occurs, the informant reports to the supervisor, after that the cause of the incident is investigated and an investigation is carried out by looking for the root of the problem.

If an incident has occurred, the hospital must immediately follow up on the report which is useful to reduce the impact of the incident. After an incident occurs a maximum of $2 \times 24$ hours reports must have been made by reporting to the direct supervisor ie the head of the room or supervisor. Immediately after making a report, the supervisor immediately analyzes the incident causing the incident. After completing the reporting, the cause of the incident is found and the risk grading is determined.

The implementation of teamwork does not yet support patient safety. The team consists of two or more individuals who have specific roles or tasks to carry out and coordinate with other members to achieve the same goal namely patient safety. The task of team members is independent of interaction with other members and is an interdependent component of performance. According to AHRQ (Agency Health Research and Quality) teamwork in creating a culture of patient safety is collaboration within the unit itself and cooperation between units in the hospital. Cooperation within the unit is how each employee respects, values and coordinates one another in order to provide quality services. Team members must be involved in the process of working on assignments to achieve common goals.

An assessment of the culture of patient safety in 630 hospitals in the United States found a positive perception of teamwork was $62 \%$ (AHRQ, 2018). Suboptimal teamwork can pose a risk of patient safety incidents. According to research conducted by Allen and Lyn (2013) that teamwork is one of the variables that influence the quality of hospital services. 
Still losing information when changing shifts / handovers Cooperation within the unit includes personal relationships between staff in a unit, whether each staff works together in providing services that support patient safety. The interview results obtained about how the patient handover / handover during shifting is as follows:

"We have directly operated to the room, from morning to evening directly to the room, immediately asked to the patient, so we know which patient" (P2L55)

"The cooperation is good, the operands are already in the sphere. For example there is a new patient directly to the patient, what patient is this? immediately indicated where the patient was. Add more now the patient's bracelet is there so it's easy to confirm the patient "(P8L41)

"Cooperation is good, but there is still a loss of information, sometimes things that make me doubtful. Usually after that we call back to the previous service (P13L110)

From the interview results above, it shows that the informant has handed over the patient well by handover directly to the patient. Although the handover they have done by doing a handover to the patient's room, but there is still a loss of patient information when changing shifts.

Regulations that do not support the creation of teamwork. The hospital is a work unit that consists of many - many parts that are interconnected. The following are the results of interviews obtained about how to collaborate with other units in the hospital:

"For example anemic patients but the patient is a history of cancer that has finished treatment, entered the surgical care room and should enter the internal medicine room. Sometimes there are patients who want to be amputated, but they don't take X-rays when they are in the emergency room, so if that's the case for the patient "(P7L21)

"But here is a regulation made for cito or sudden laboratory examinations. The new regulation is that the laboratory has a schedule for when to take patient samples, so outside the schedule, nurses take samples for examination. yes. If there are patients who check blood sugar, nurses do the work, even though it is not our job "(P13L120)

"For patients who have just entered from the emergency room, sometimes it is still incomplete, sometimes the examination is incomplete, sometimes there is no examination" (P19L80)

"The emergency room may convey information, but the one who delivers the inpatient room is kak Idet (a junior high school graduate employee assigned to take care of the patient room), with the reason that many patients are in the emergency room so that nurses cannot accompany to deliver the spatial patient. it "(P19L57)

"..... if the labor results are slow" (P28L86).

From the results of the above research it can be shown that there are two units whose collaboration is not very supportive for patient safety, namely laboratories and emergency departments. Informants assume the rules made related to hours of blood sampling for examination of patients are regulations that can cause the risk of patient safety incidents. In addition, the officer who took the patient to the inpatient room was not accompanied by a nurse to be one of the causes of information loss when delivering the patient, because the officer did not understand the patient's condition and what happened to the patient. 


\section{Conclusion}

The conclusions of this study found seven themes, namely:

1. Management support in creating patient safety is focused only on accreditation assessments.

2. There are still facilities and infrastructure available in a state of damage and do not meet the needs.

3. Lack of socialization about reporting systems for patient safety incidents and many of their patient safety incidents that are not reported.

4. There is no specific training related to patient safety

5. There is no open communication and there is still a culture of blame if an incident occurs.

6. There is no future learning after the incident

7. Policies made by hospitals do not support the creation of patient safety.

\section{References}

Agustina, C., Dwiantoro, L., \& Warsito, B. E. (2018). Komunikasi efektif perawat dalam patient safety: literatur review (Skripsi Fakultas Kedokteran Universitas Diponegoro Semarang, Indonesia). Diakses dari http:e/prints.undip.ac.id/73888/

Allen, C., \& Lynn. (2013). Role of a quality management system in improving patient safety - Laboratory Aspects.. Clinical biochemistry. Diakess dari 10.1016/j.clinbiochem.2013.04.028.

Alquwez, N., Cruz, J. P., Almoghairi, A. M., Al-otaibi, R. S., Almutairi, K. O., Alicante, J. G., \& Colet, P. C. (2018). Nurses' perceptions of patient safety culture in three hospitals in Saudi Arabia. Journal of Nursing Scholarship, 50(4), 422-431.

Ammouri, A. A., Tailakh, A. K., Muliira, J. K., Geethakrishnan, R., \& Al Kindi, S. N. (2015). Patient safety culture among nurses. International Nursing Review, 62(1), 102-110.

Anggraeni, D., \& Azzuhri, M. (2016). Pengaruh budaya keselamatan pasien terhadap sikap melaporkan insiden pada perawat di Instalasi Rawat Inap Rumah Sakit Tk. II dr. Soepraoen. Jurnal Aplikasi Manajemen, 14(2), 309-321.

Arini, T. P., Yulia, S., \& Romiko, R. (2018). Hubungan kerjasama tim dengan penerapan budaya keselamatan pasien di ruang rawat inap Rumah Sakit Bhayangkara Palembang Tahun 2018. Masker Medika, 6(2), 406-416.

Carayon, P., Schoofs Hundt, A., Karsh, B. T., Gurses, A. P., Alvarado, C. J., Smith, M., \& Flatley Brennan, P. (2005). Work system design for patient safety: the SEIPS model. Quality \& safety in health care, 15 Suppl 1(Suppl 1), i50-i58. doi:10.1136/qshc.2005.015842

Choo, J. Hutchinson, A., \& Bucknall, T. (2010). Nurses role in medication safety. Journal of nursing management, 18(15).

Cho, S. M., \& Choi, J. S. (2018). Patient safety culture associated with patient safety competencies among registered nurses. Journal of Nursing Scholarship, 50(5), 549-557. doi:http://dx.doi.org/10.1111/jnu.12413

Famolaro, T., Yount, N., \& Hare, R. (2018). Hospital survey on patient safety culture 2018 user database report. (Prepared by Westat, Rockville, MD, under Contract No. HHSA 290201300003C). Rockville, MD: agency for healthcare research and quality. AHRQ Publication No. 180025-EF.

Fan, C. J., Pawlik, T. M., Daniels, T., Vernon, N., Banks, K., Westby, P., ... \& Makary, M. A. (2016). Association of safety culture with surgical site infection outcomes. Journal of the American College of Surgeons, 222(2), 122-128.

Fatimah, F. S., \& Rosa, E. M. (2016). Efektivitas Pelatihan patient safety; komunikasi s-bar pada perawat dalam menurunkan kesalahan pemberian obat injeksi di Rumah Sakit PKU Muhammadiyah Yogyakarta Unit II. Jurnal Ners dan Kebidanan Indonesia, 2(1), 32-41.

Febriyaty, D., \& Utami, D. (2019). Gambaran budaya keselamatan pasien berdasarkan metode 
AHRQ Pada Pegawai RS. Anna Medika Kota Bekasi Tahun 2018. Jurnal Biologi Lingkungan, Industri, Kesehatan), 5(2), 97-105.

Gunawan, G., Harijanto, H., \& Harijanto, T. (2015). Analisis rendahnya laporan insiden keselamatan pasien di rumah sakit. Jurnal Kedokteran Brawijaya, 28(2), 206-213.

Hamali, Y/ A. (2018). Pemahaman manajemen sumber daya manusia. Jakarta : Putaka Pelajar

Harus, B. D., \& Sutriningsih, A. (2015). Pengetahuan perawat tentang keselamatan pasien dengan pelaksanaan prosedur keselamatan pasien rumah sakit (KPRS) di Rumah Sakit Panti Waluya Sawahan Malang. Care: Jurnal Ilmiah Ilmu Kesehatan, 3(1), 25-32.

Harsul, W., Syahrul, S., \& Majid, A. (2018). Penerapan budaya pelaporan insiden keselataman pasien di sebuah RSU Daerah Provinsi Sulawesi Selatan. Panrita Abdi-Jurnal Pengabdian pada Masyarakat, 2(2), 119-126.

Hermawan, D., Junika, E., \& Nadeak, J. (2018). Hubungan kepatuhan perawat melaksanakan standar prosedur operasional (SPO) cuci tangan terhadap kejadian phlebitis di Rumah Sakit Graha Husada Bandar Lampung Tahun 2018. Holistik Jurnal Kesehatan, 12(3), 196-204.

Hidayati, R. I. (2015). Pengarub pengetahuan, motivasi, sikap perawat dan bidan terhadap penerapan budaya patient safety di RSLA 'Aisyiyah Klaten (Tesis Pascasarjana. Yogyakarta: UMY). Diakses dari http://docplayer-info.cdn.ampproject.org/v/s/docplayer/info/amp/35211262-Pengaruh-

Himatusujanah, H., \& Rahayuningsih, F. B. (2017). Hubungan tingkat kepatuhan pelaksanaan protap perawatan luka dengan kejadian infeksi luka post sectio caesarea (SC) di Ruang Mawar I RSUD DR. Moewardi Surakarta. Berita Ilmu Keperawatan, 1(4), 175-180.

Huang, D.T., Clermont, G., Kong, L., Weissfeld, L.A., Sexton, JB., Rowan, K.M., Angus, D.C. (2010). Intersive care unit safety culture and outcomes: a us multicenter study. Int J Qual bealth Care. 22(3), $152-61$.

Idris, H. (2017). Dimension of patient safety culture. Jurnal Ilmu Kesehatan Masyarakat, 8(1).

Institute of Medicine (US) Committee on the work environment for nurses and patient safety; Page A, editor. Keeping patients safe: transforming the work environment of nurses. Washington (DC): National Academies Press (US); 2004. Diakses dari https://www.ncbi.nlm.nih.gov/books/ NBK216190/ doi: 10.17226/10851

Institute of Medicine. (2000). To Err Is Human: Building a Safer Health System. Washington, DC: The National Academies Press. doi: 10.17226/9728.

Iriviranty, A. (2018). Analisis budaya organisasi dan budaya keselamatan pasien sebagai langkah pengembangan keselamatan pasien di RSIA Budi Kemuliaan Tahun 2014. Jurnal Administrasi Rumah Sakit Indonesia, 1(3).

Iskandar, H., Wardhani, V., \& Rudijanto, A. (2016). Faktor-faktor yang mempengaruhi niat melapor insiden keselamatan pasien. Jurnal Aplikasi Manajemen, 14(3), 492-498.

Jian-fei Xie, Si-qing Ding, Zhu-qing, Z., Sai-nan Zeng, Chun-xiang, Q., Qi-feng, Y., . . Jian-da Zhou. (2017). A safety culture training program enhanced the perceptions of patient safety culture of nurse managers. Nurse Education in Practice, 27, 128-133. doi:http://dx.doi.org/10.1016/ j.nepr.2017.08.003

Martha, E., Kresno, S. (2017). Metodologi penelitian kualitatif untuk bidang kesehatan. Depok : RajaGrafindo Persada.

Martyastuti, N. E., Dharmana, E., \& Hidayati, W. (2016). Hubungan antara faktor individu dan persepsi organisasi dengan kinerja perawat pelaksana dakam penerapan keselamatan pasien di ruang rawat inap RSUD Bendan Kota Pekalongan (Doctoral dissertation, Diponegoro). Diakses dari http://eprints.undip.ac.id/51165/1/Proposal_Fix.pdf

Mitchell, I., Schuster, A., Smith, K., Pronovost, P., \& Wu, A. (2016). Patient safety incident reporting: a qualitative study of thoughts and perceptions of experts 15 years after 'To Err is Human'. BMJ Qual Saf, 25(2), 92-99.

Mitchell, P.H. (2018). Defining patient safety and quality care. in: hughes rg, editor. patient safety 
and quality: An Evidence-Based Handbook for Nurses. Rockville (MD): Agency for Healthcare Research and Quality (US). Diakses dari https://www.ncbi.nlm.nih.gov/books/NBK2681/

Moleong. (2016). Metode penelitian kualitatif. Bandung: Rosda

Morgan, M. S., Berger, I., Jennifer S. M., Judy A. S., Jon B. M., Rachel R.K. (2018). Using patient safety reporting systems to understand the clinical learning environment: a content analysis. Journal of Surgical Education, 75(6), e168-e177.

Peraturan Menteri Kesehatan Republik Indonesia Nomor 11 Tahun 2017 tentang keselamatan pasien

Pohan, S, I. (2015). Jaminan mutu layanan kesehatan. Jakarta : EGC

Pratiwi, A., Sudiro, S., \& Fatmasari, E. Y. (2017). Analisis Persepsi perawat terhadap budaya keselamatan pasien dengan pendekatan institute for healthcare improvement di RSJD Dr. Amino Gondohutomo Kota Semarang. Jurnal Kesehatan Masyarakat (e-Journal), 5(1), 32-39.

Pujilestari, A., Maidin, A., \& Anggraeni, R. (2016). Budaya keselamatan pasien di instalasi rawat inap RSUP DR. Wahidin Sudirohusodo Kota Makassar. Media Kesehatan Masyarakat Indonesia, 10(1), 57-64.

Purwanto. (2018). Pedalaman materi keperawatan modul 14. Jakarta: Grafika Aditama.

Rachmawati, A. R., Wigati, P. A., \& Sriatmi, A. (2017). Analisis pelaksanaan tujuh langkah menuju keselamatan pasien di rumah sakit Islam Sultan Agung Semarang. Jurnal Kesehatan Masyarakat (e-Journal), 5(1), 1-7.

Rahayu, S. B. (2017). Pengaruh dimensi staffing terhadap insiden keselamatan pasien berdasarkan agency for healthcare research and quality (AHRQ) di RSU Haji Surabaya. Jurnal Administrasi Kesehatan Indonesia, 5(1), 41-51.

Rieibowo, C., \& Harahap, Z. (2016). Studi kulitatif : peran handover dalam meningkatkan keselamatan pasien di rumah sakit. Pena Medika Jurnal Kesehatan, 6(2).

Robbins, P, S., Judge, A, T. (2008). Perilaku organisasi. Jakarta : Salemba empat

Sakit, K. K. P. R. (2015). Pedoman Pelaporan insiden keselamatan pasien (IKP) (patient safety incident report). Jakarta: KARS.

Vincent, C. (2011). Patient Safety, 2nd edition. By Charles Vincent. Published 2010 by Blackwell Publishing Ltd. Diakses dari https://www.wiley.com/enus/Patient+Safety\%2C+2nd+Edition-p-978140519221

Walker, J. (2018). Nurses' perception of their role in patient safety (Order No. 10824279). Available from ProQuest Dissertations \& Theses Global. (2050014156). Diakses dari https://search.proquest.com/docview/20500 14156?accountid $=50257$

Wright, J., \& Hill, P. (2003). Clinical Governance. Edinburgh London New York Philadelpha St Louis Sydney Toronto : Churcill Livingstone

World Health Organization. (2018). Diakses dari ttps://www.who.int/ patientsafety/policies/ministerial_summit_18/en/

World Health Organization. (2019). Patient Safety. Diakses dari https://www.who.int/patientsafety/medication-safety/campaign/en/.

Yudhawati, D. D., \& Listiowati, E. (2016). Evaluasi penerapan identifikasi pasien di bangsal rawat inap RSI Siti Aisyah Madiun. JMMR (Jurnal Medicoeticolegal dan Manajemen Rumab Sakit), 4(2).

Yulia, S., Hamid, A. Y. S., \& Mustikasari, M. (2012). Peningkatan pemahaman perawat pelaksana dalam penerapan keselamatan pasien melalui pelatihan keselamatan pasien. Jurnal Keper 